\title{
Flicker Light Effects on Photosynthesis of Symbiotic Algae in the Reef- Building Coral Acropora digitifera (Cnidaria: Anthozoa: Scleractinia) ${ }^{1}$
}

\author{
Takashi Nakamura ${ }^{2,3}$ and Hideo Yamasaki ${ }^{2,4}$
}

\begin{abstract}
Reef-building corals inhabit a variety of aquatic habitats with a range of light conditions. Because the coral host depends on photosynthetic products assimilated from endosymbiotic algae, reef-building corals have to cope with irradiance fluctuations on instantaneous to seasonal time scales. Underwater highfrequency light fluctuations resulting from the lens effect on the water surface are prominent in oligotrophic coral reef environments, a phenomenon known as flicker light. Effects of flicker light on endosymbiont photosynthesis of the reef-building coral Acropora digitifera (Dana, 1846) were evaluated with pulse amplitude modulation chlorophyll fluorometry. At supersaturating light intensities, photosynthesis was less inhibited by flicker light than by constant light. Reduction in photoinhibition by flicker light was pronounced at high water temperatures. Flicker light may strongly influence endosymbiont photosynthesis of corals inhabiting shallow reef habitats, especially during periods of strong solar irradiance and high water temperature.
\end{abstract}

REEF-BUILDING CORALS flourish in shallowwater habitats in the subtropics and tropics, where strong sunlight reaches much deeper than in temperate oceans. Oligotrophic seawater limits phytoplankton blooms, resulting in transparent water conditions on coral reef habitats. To adapt to the oligotrophic conditions and high solar irradiance, reef-building corals have evolved a symbiosis with dinoflagellates (zooxanthellae) in which algal photosynthesis provides essential energy for the host animal (Muscatine 1967). For most

${ }^{1}$ This work was supported by a Grant-in-Aid from the Japan Society for the Promotion of Science for research fellows to T.N., and by a Grant-in-Aid for H.Y. and T.N. by the 21st Century Center of Excellence (COE) Program of the University of the Ryukyus from the Ministry of Education, Culture, Sports, Science, and Technology, Japan. Manuscript accepted 24 August 2007.

2 Faculty of Science, University of the Ryukyus, Nishihara, Okinawa 903-0213, Japan.

${ }^{3}$ Amakusa Marine Biological Laboratory, Kyushu University, Tomioka, Reihoku-Amakusa, 863-2507, Kumamoto, Japan.

${ }^{4}$ Author for correspondence (e-mail: yamasaki@sci.u -ryukyu.ac.jp).

Pacific Science (2008), vol. 62, no. 3:341-350

(C) 2008 by University of Hawai'i Press

All rights reserved reef-building corals, therefore, symbiosis is obligatory, and the corals cannot survive without algal photosynthesis. In this context, similar to terrestrial plants, light is an important determinant factor for growth and survival of reef-building corals.

On a sunny day, ripples on the water surface cause considerable heterogeneity of subsurface light through a lens effect that simultaneously focuses and diffuses sunlight in the upper few meters (Drew 1983, Larkum and Barrett 1983), producing a constantly moving pattern of interspersed light and shadows on the substrate (Figure $1 A$ and $B$ ). Due to the lens effect, light intensity in shallow-water environments sometimes reaches more than $9,000 \mu \mathrm{mol}$ photons $\mathrm{m}^{-2}$ $\mathrm{sec}^{-1}$, corresponding to 300 to $500 \%$ of the surface light intensity (Schubert et al. 2001, in shallow estuary). The lens effect produced by waves generates narrow belts of supersaturating light (e.g., more than $500 \%$ of the ambient light intensity) that pass over the bottom surface for less than a second. In addition to the focusing effect of light, curvature of the water surface also produces a lower light intensity regime, namely, a light defusing effect (Schubert et al. 2001). The light diffusing effect may serve as a relaxation period for algal photosynthesis. 

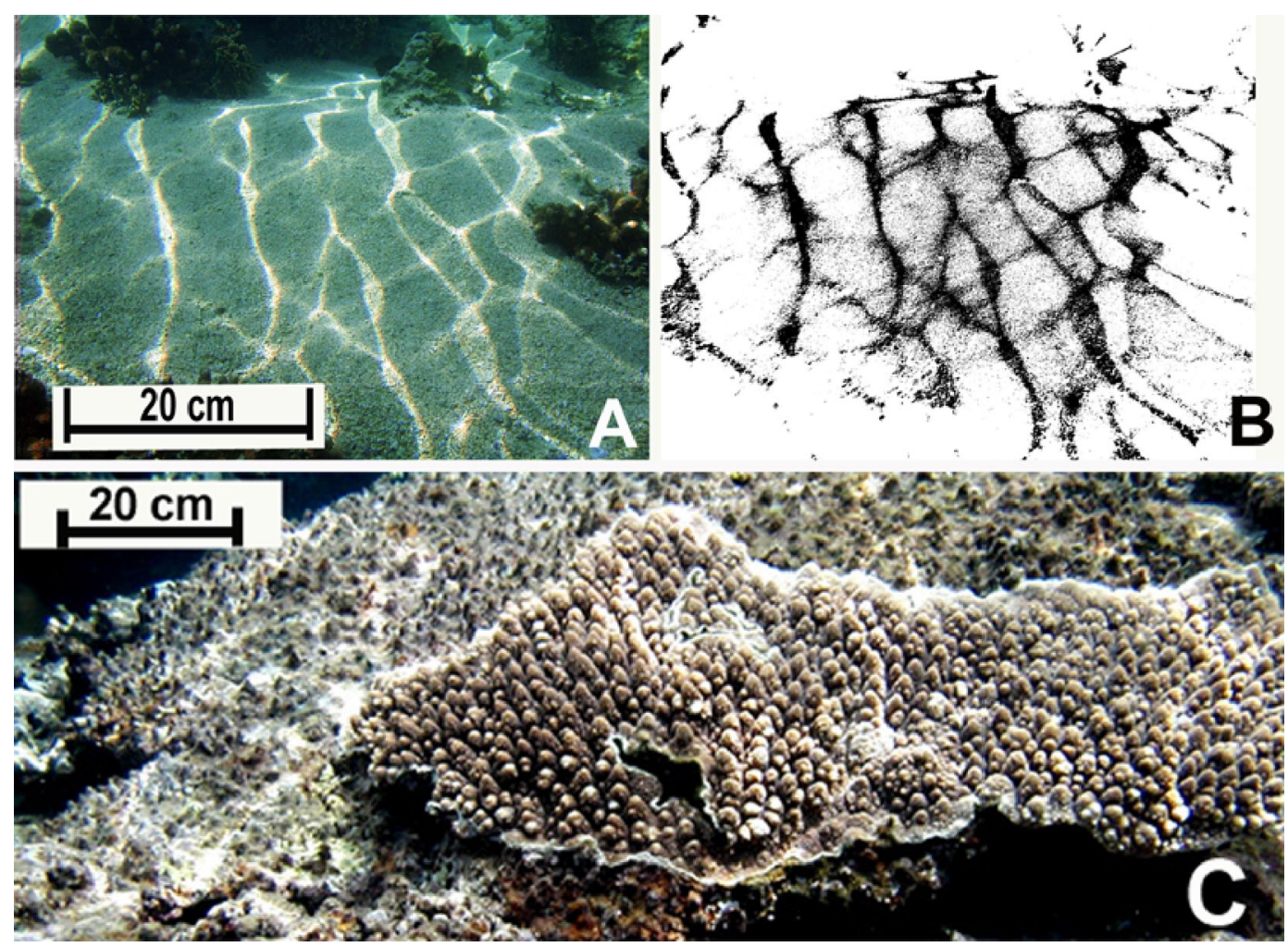

FIgURE 1. Flicker light: $(A)$ on a coral reef substrate; $(B)$ digital processing of the original photo to enhance the high light regimes; $(C)$ shallow reef environments where flicker light is common predominantly inhabited by Acropora digitifera. Photos were taken at Bise, Okinawa, Japan.

Although light is essential for photosynthesis, excessively strong light destroys the photosynthetic apparatus, a phenomenon referred to as photoinhibition or photodamage (Barber and Andersson 1992, Aro et al. 1993). Photoinhibition refers to both reversible and irreversible effects of excessive light on a photosynthetic apparatus (Osmond 1994), and photodamage refers specifically to irreversible effects. Recent studies have suggested that photoinhibition is involved in the initial stage of coral bleaching (Jones and HoeghGuldberg 2001, Warner et al. 2002), especially in shallow habitats where corals are exposed to strong irradiance during low tide (Jokiel 1980, Falkowski et al. 1990, Brown et al. 1994, 2000, Kirk 1994). Until recently, there has been little information on the effects of flicker light on coral photosynthesis.
Because flicker light potentially produces excessively strong light as well as dimmer light intensities, such fluctuations may have profound effects on photosynthesis of shallow corals. We conducted a series of laboratory experiments with the reef-building coral Acropora digitifera (Dana, 1846), a species predominantly found in shallow reef habitats (Figure $1 C$ ), to examine the effects of flicker light on photoinhibition of coral photosynthesis.

MATERIALS AND METHODS

\section{Sample Preparation}

Branching colonies of Acropora digitifera (Figure $1 C)$ were collected from a shallow $(<1 \mathrm{~m}$ low-tide depth) reef flat at Bise reef, northern 
Okinawa Island, Japan, in August 2004. Coral colonies were immediately broken into small branches (4-5 cm length) using a chisel and hammer. Each branch was attached to a 2 $\mathrm{cm}$ polycarbonate screw using superglue (Alone-alpha, Toagosei, Japan). Samples were kept in an outdoor aquarium (1.0 by 2.0 by $0.6 \mathrm{~m}$, supplied with 5 liters $\mathrm{min}^{-1}$ seawater) at Sesoko Tropical Biosphere Research Station, University of the Ryukyus, Japan. Sunlight intensity was attenuated by black nylon mesh (approx. 50\% reduction). The water surface was continuously stirred by underwater pumps (RSD-40, Iwaki Pumps, Japan) along with aeration bubbles. Samples were acclimatized in the tank for 10 months before the experiments.

Photochemical efficiency, measured as maximum electron transport rate in Photosystem II (a protein complex embedded in thylakoid membrane of chloroplast that uses light to reduce molecules for photochemical reaction in photosynthesis) (Schreiber et al. 1986, 1995), depends on light intensity. For example, the maximum electron transfer rate (ETR) in algal symbionts of $A$. digitifera was achieved at $200 \mu \mathrm{mol}$ photons $\mathrm{m}^{-2} \mathrm{sec}^{-1}$, and it showed a steep decline at a light intensity higher than $500 \mu \mathrm{mol}$ photons $\mathrm{m}^{-2} \mathrm{sec}^{-1}$, indicating light-induced inhibition of photosynthesis (i.e., photoinhibition [Figure 2]). Based on these results, we applied a light intensity of $80 \mu \mathrm{mol}$ photons $\mathrm{m}^{-2} \mathrm{sec}^{-1}$ as a subsaturating light condition (nonharmful light condition) and $500 \mu \mathrm{mol}$ photons $\mathrm{m}^{-2}$ $\mathrm{sec}^{-1}$ as a supersaturating light condition (excessively strong light condition) in the following experiments. During the experiment, the light intensity was checked every 5 min using the photosynthetically active radiation sensor (SA40 LI-COR).

\section{Measurement of Chlorophyll Fluorescence}

To assess photosynthetic response of the in hospite (symbiont in the intact state within the host cell) symbiotic algae within $A$. digitifera, we measured chlorophyll $a$ fluorescence emitted from the algae with a Diving pulse amplitude modulation fluorometer (Walz, Effeltrich, Germany). Maximum potential

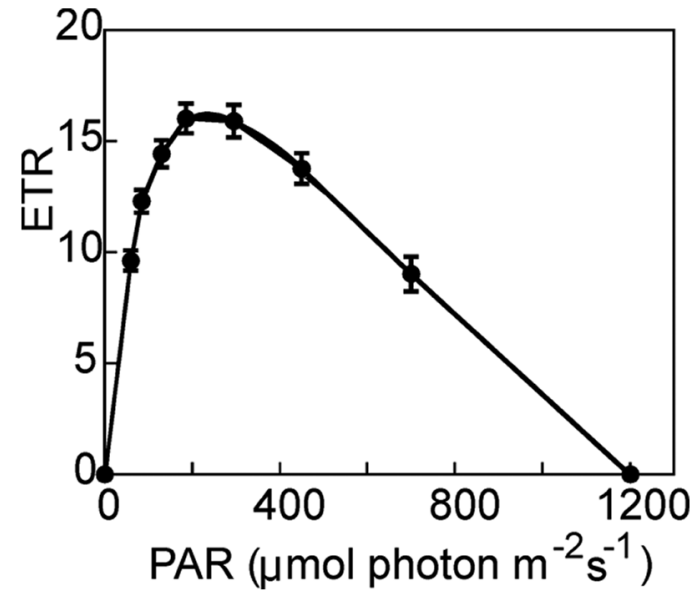

Figure 2. Rapid light curve $(n=5)$ of A. digitifera obtained by illuminating dark-adapted samples from zero to $1,200 \mu \mathrm{mol}$ photons $\mathrm{m}^{-2} \mathrm{sec}^{-1}$ in eight steps of 10 sec. The effective quantum yield of Photosystem II $(\Delta F /$ $\left.F m^{\prime}\right)$ during steady-state photosynthesis of the lightadapted samples was calculated as $\left(F m^{\prime}-F\right) / F m^{\prime}$. The apparent rate of photosynthetic electron transport through Photosystem II (electron transfer rate [ETR]) was obtained as $0.5 \times \Delta F / F m^{\prime} \times$ photosynthetically active radiation (wavelength $400-700 \mathrm{~nm}$ ).

yield of Photosystem II was calculated from $\left[F_{v} / F_{m}=\left(F_{m}-F_{o}\right) / F_{m}\right] \quad$ (Schreiber et al. 1986). Dark-adapted $F v / F m$ is a reliable measure of the photochemical efficiency of Photosystem II (Demmig and Bjorkman 1987), and decrease in $\mathrm{Fv} / \mathrm{Fm}$ value has been applied as a good indicator to monitor photoinhibition of photosynthesis (Franklin et al. 1992). In our study we used $\mathrm{Fv} / \mathrm{Fm}$ to assess photoinhibition of in hospite algal photosynthesis (Takahashi et al. 2004).

For the subsaturating light regime experiments, samples were kept at $28^{\circ} \mathrm{C}$. Control samples were exposed to a constant light intensity of $80 \mu \mathrm{mol}$ photons $\mathrm{m}^{-2} \mathrm{sec}^{-1}$ for 60 min. Three flicker light treatments were examined to investigate effects of short-term light fluctuation on symbiont photosynthesis (flicker treatments 1-3): (1) $0.2 \mathrm{sec}$ of 3,000 $\mu \mathrm{mol}$ photons $\mathrm{m}^{-2} \mathrm{sec}^{-1}$ followed by $9.8 \mathrm{sec}$ of $20 \mu \mathrm{mol}$ photons $\mathrm{m}^{-2} \mathrm{sec}^{-1}$ as background light, (2) $0.4 \mathrm{sec}$ of $2,000 \mu \mathrm{mol}$ photons $\mathrm{m}^{-2}$ $\mathrm{sec}^{-1}$ followed by $9.6 \mathrm{sec}$ of $20 \mu \mathrm{mol}$ photons $\mathrm{m}^{-2} \mathrm{sec}^{-1}$ as background light, (3) $2.6 \mathrm{sec}$ of 
TABLE 1

Compound Table Showing (a) Results of Two-Way Analysis of Variance (ANOVA) of Changes in Fv/Fm in Acropora digitifera Where Subsaturating Light Regime Treatments and Time Are Fixed Effects and (b) Results of Tukey HSD Multiple Comparison Test on Significant Differences among Fv/Fm of Control (C) and Flicker Light Treatments $(1,2,3)$ Initially (I) and after 60-Min Exposure Period (A)

\begin{tabular}{|c|c|c|c|c|c|c|c|}
\hline (a) Two-way ANOVA results & \multicolumn{2}{|c|}{$\mathrm{df}$} & MS & \multicolumn{3}{|c|}{$F$} & $P$ Level \\
\hline Light treatment (L) & \multicolumn{2}{|c|}{3} & 0.0005 & \multicolumn{3}{|c|}{4.7439} & ** \\
\hline Time $(\mathrm{T})$ & \multicolumn{2}{|c|}{1} & 0.0017 & \multicolumn{3}{|c|}{16.1856} & $* * *$ \\
\hline $\mathrm{L} \times \mathrm{T}$ & \multicolumn{2}{|c|}{3} & 0.0010 & \multicolumn{3}{|c|}{9.3234} & *** \\
\hline Error & & & 0.0001 & & & & \\
\hline (b) Post-hoc results & C-A & F1-I & F1-A & F2-I & F2-A & F3-I & F3-A \\
\hline Control Initial (C-I) & NS & NS & NS & NS & NS & NS & $* * *$ \\
\hline Control After (C-A) & & NS & NS & NS & NS & NS & ** \\
\hline Flicker 1 Initial (F1-I) & & & NS & NS & NS & NS & $* * *$ \\
\hline Flicker 1 After (F1-A) & & & & NS & NS & NS & $* * *$ \\
\hline Flicker 2 Initial (F2-I) & & & & & NS & NS & $* * *$ \\
\hline Flicker 2 After (F2-A) & & & & & & NS & ** \\
\hline Flicker 3 Initial (F3-I) & & & & & & & $* * *$ \\
\hline Flicker 3 After (F3-A) & & & & & & & \\
\hline
\end{tabular}

Note: Asterisks indicate significant difference: ${ }^{*}, P<.05 ;{ }^{* *}, P<.01 ;{ }^{* * *}, P<.001$; NS, no significant difference.

$310 \mu \mathrm{mol}$ photons $\mathrm{m}^{-2} \mathrm{sec}^{-1}$ followed by 7.4 sec of $5 \mu \mathrm{mol}$ photons $\mathrm{m}^{-2} \mathrm{sec}^{-1}$ as background light. These patterns were repeated every $10 \mathrm{sec}$ for $60 \mathrm{~min}$. Dark-adapted Fv/ $\mathrm{Fm}$ was measured before and after the light exposure period ( $n=5$ colonies in each treatment).

For the supersaturating light regime experiments, samples were kept at $28^{\circ} \mathrm{C}$. Control samples were exposed to the constant light intensity of $500 \mu \mathrm{mol}$ photons $\mathrm{m}^{-2}$ $\mathrm{sec}^{-1}$. Four flicker light treatments were applied to the corals (flicker treatments A-D): (A) $3 \mathrm{sec}$ of $650 \mu \mathrm{mol}$ photons $\mathrm{m}^{-2} \mathrm{sec}^{-1}$ followed by $7 \mathrm{sec}$ of $450 \mu \mathrm{mol}$ photons $\mathrm{m}^{-2}$ $\mathrm{sec}^{-1}$, (B) 3 sec of $1,000 \mu \mathrm{mol}$ photons $\mathrm{m}^{-2}$ $\mathrm{sec}^{-1}$ followed by $7 \mathrm{sec}$ of $290 \mu \mathrm{mol}$ photons $\mathrm{m}^{-2} \mathrm{sec}^{-1}$, (C) $3 \mathrm{sec}$ of $1,300 \mu \mathrm{mol}$ photons $\mathrm{m}^{-2} \mathrm{sec}^{-1}$ followed by $7 \mathrm{sec}$ of $160 \mu \mathrm{mol}$ photons $\mathrm{m}^{-2} \mathrm{sec}^{-1}$, (D) $3 \mathrm{sec}$ of $1,700 \mu \mathrm{mol}$ photons $\mathrm{m}^{-2} \mathrm{sec}^{-1}$ followed by $7 \mathrm{sec}$ of $20 \mu \mathrm{mol}$ photons $\mathrm{m}^{-2} \mathrm{sec}^{-1}$. These patterns were repeated every $10 \mathrm{sec}$ for $60 \mathrm{~min}$. Dark-adapted $\mathrm{Fv} / \mathrm{Fm}$ was measured before and after the light exposure period $(n=5$ colonies in each treatment).

For the temperature-controlled experiments, effects of constant light of $500 \mu \mathrm{mol}$ photons $\mathrm{m}^{-2} \mathrm{sec}^{-1}$ and flicker treatment $\mathrm{C}$ were examined at four different temperatures $\left(28,30,32\right.$, and $\left.34^{\circ} \mathrm{C}\right)$. Dark-adapted Fv/Fm was measured before and after the 60-min exposure period $(n=5$ colonies in each treatment).

In the artificial flicker light experiments, the integral light intensity per hour was kept constant (e.g., 84-85 mol photons $\mathrm{m}^{-2} \mathrm{sec}^{-1}$ for subsaturating light experiments or 500 $524 \mu \mathrm{mol}$ photons $\mathrm{m}^{-2} \mathrm{sec}^{-1}$ for supersaturating light experiments and temperaturecontrolled experiments). All the light exposure programs were carried out using the controls on the pulse amplitude modulation fluorometer.

Results were subjected to analysis of variance (ANOVA), and mean values were compared by the Tukey's test $(P=.05)$. A twoway ANOVA was used to test for significance in $\mathrm{Fv} / \mathrm{Fm}$ differences among subsaturating light treatments $(\mathrm{df}=3)$ at initial and at 60 min exposure time. A two-way ANOVA was used to test for significance in $\mathrm{Fv} / \mathrm{Fm}$ differences among supersaturating light treatments $(\mathrm{df}=4)$ at initial and at 60 -min exposure time. A three-way ANOVA was used to test for significant differences in the interaction among light treatments $(\mathrm{df}=1)$, time $(\mathrm{df}=1)$, and temperatures $(\mathrm{df}=3)$. Homo- 
geneity of variance and normality were first determined, and transformations were used when necessary. The post hoc Tukey HSD procedure was used for multiple group comparisons. The statistical analyses were performed using Statistica software (Version 5.5, StatSoft, USA).

\section{RESULTS}

At $28^{\circ} \mathrm{C}$ and subsaturating light intensity, the control group (constant light intensity of 80 $\mu \mathrm{mol}$ photons $\mathrm{m}^{-2} \mathrm{sec}^{-1}$ ) did not show a reduction in $F v / F m$ after $60 \mathrm{~min}$ (Table 1, Figure 3), indicating that photoinhibition did not occur. Flicker treatments 1 and 2 did not show reductions in $F v / F m$ after $60 \mathrm{~min}$ or differences in $F v / F m$ from the control (Table 1, Figure 3). However, flicker treatment 3 resulted in decreased $\mathrm{Fv} / \mathrm{Fm}$ after $60 \mathrm{~min}$ and differences in $F v / F m$ from the control (Table 1, Figure 3).

At $28^{\circ} \mathrm{C}$ and supersaturating light intensity, the control group (constant light intensity of $500 \mu \mathrm{mol}$ photons $\mathrm{m}^{-2} \mathrm{sec}^{-1}$ ) showed a decline in $\mathrm{Fv} / \mathrm{Fm}$ after $60 \mathrm{~min}$ (Table 2, Figure 4). Flicker treatments A and B showed

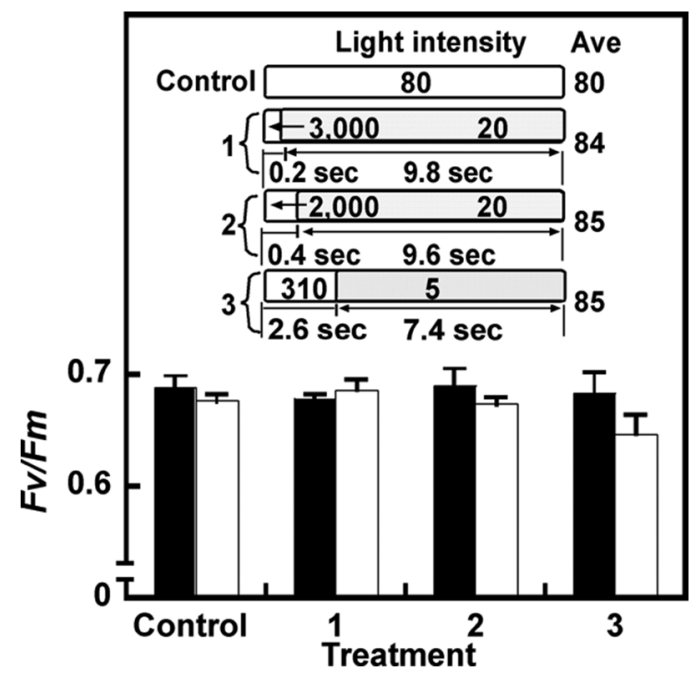

Figure 3. Fv/Fm (mean $\pm \mathrm{SD}, n=5$ ) for $A$. digitifera before (black bar) and after 60 min (white bar) of exposure to subsaturating light. Integral light intensity was identical among four treatments $(80$ to $85 \mu \mathrm{mol}$ photons $\left.\mathrm{m}^{-2} \mathrm{sec}^{-1}\right)$. Flicker treatments data are presented in the inset.

TABLE 2

Compound Table Showing (a) Results of Two-Way Analysis of Variance (ANOVA) of Changes in Fv/Fm in Acropora digitifera Where Supersaturating Light Regime Treatments and Time Are Fixed Effects and (b) Results of Tukey HSD Multiple Comparison Test on Significant Differences among the Fv/Fm of Control (C) and Flicker Light Treatments (A, B, C, D) Initially (I) and after 60-Min Exposure Period (A)

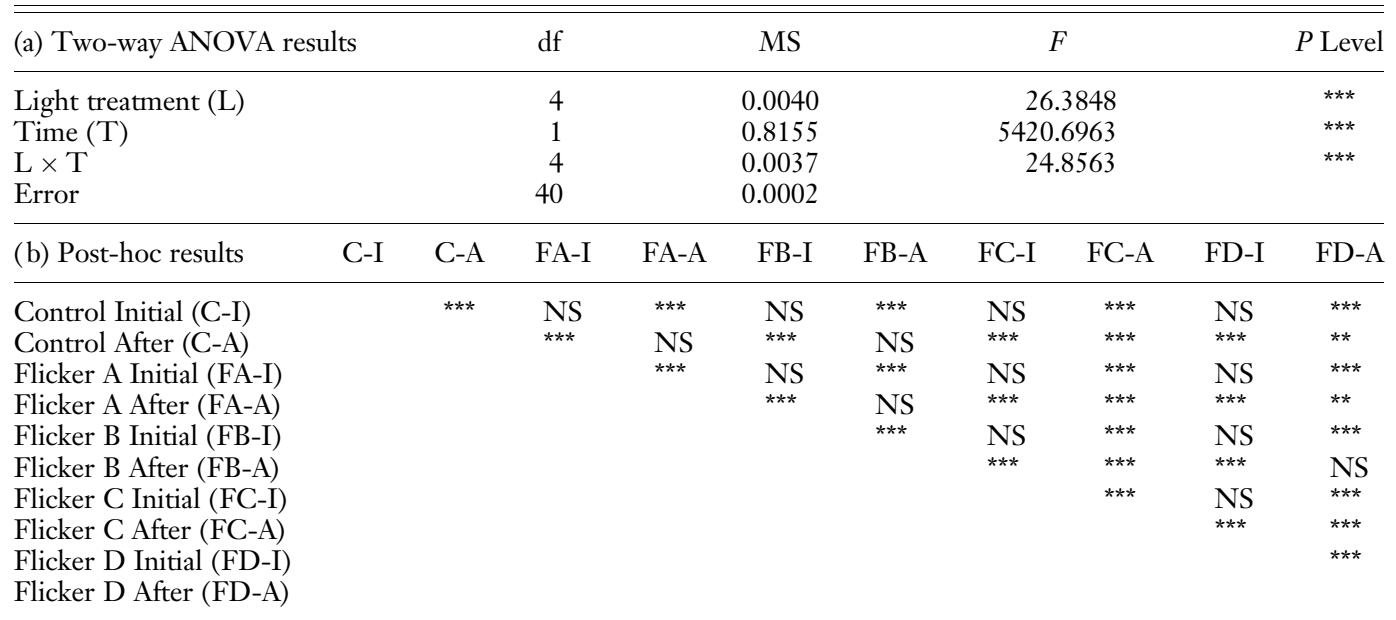

Note: Asterisks indicate significant difference: ${ }^{*}, P<.05 ;{ }^{* *}, P<.01 ;{ }^{* * *}, P<.001$; NS, no significant difference. 


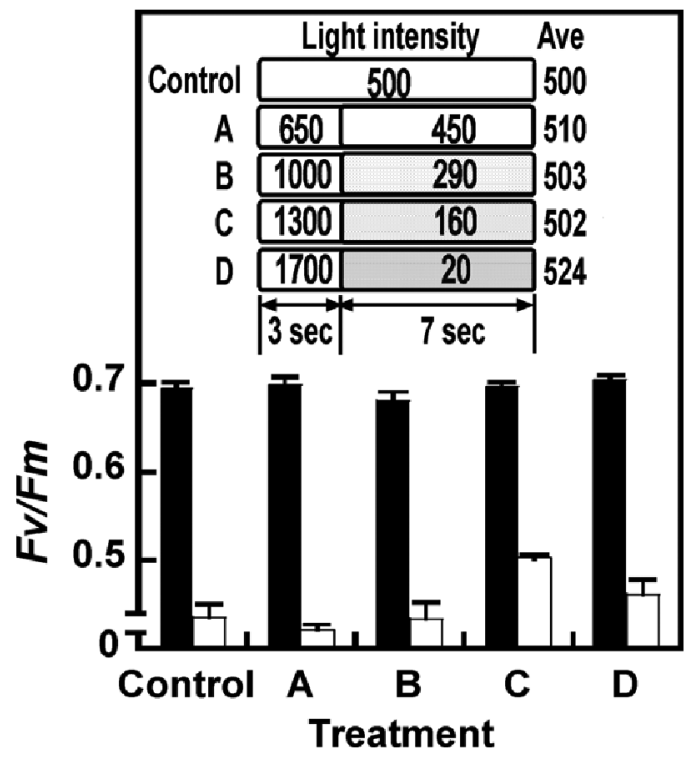

Figure 4. Fv/Fm (mean $\pm \mathrm{SD}, n=5$ ) for $A$. digitifera before (black bars) and after $60 \mathrm{~min}$ (white bars) of exposure to supersaturating light. Integral light intensity was identical among five treatments (500 to $524 \mu \mathrm{mol}$ photons $\left.\mathrm{m}^{-2} \mathrm{sec}^{-1}\right)$. Flicker treatments data are presented in the inset.

similar reductions in $\mathrm{Fv} / \mathrm{Fm}$ after $60 \mathrm{~min}$ or no differences in $\mathrm{Fv} / \mathrm{Fm}$ from the control (Table 2, Figure 4). However, Flicker treatments $\mathrm{C}$ and $\mathrm{D}$ resulted in higher $\mathrm{Fv} / \mathrm{Fm}$ than the control group (Table 2, Figure 4), indicating that the flicker treatments reduced photoinhibition.

Effects of Flicker treatment $\mathrm{C}$ were examined at four different temperatures (28, 30, 32 , and $\left.34^{\circ} \mathrm{C}\right)$. The results showed that the effect of temperature on photoinhibition was significant in $A$. digitifera. The significant temperature-time interaction suggests that the effect of temperature on photoinhibition (the time effect in ANOVA) depends on temperature. Photoinhibition in flicker light was lower (i.e., $\mathrm{Fv} / \mathrm{Fm}$ was higher) than in constant light at each temperature (Table 3, Figure 5). The average difference between the constant and flicker light treatments at each temperature was $0.066(\sim 10 \%$ of initial $\mathrm{Fv} /$ $F m$ value).

\section{DISCUSSION}

Light intensity on the earth's surface depends on solar angle, as well as the degree of scattering and absorption of sunlight by the atmosphere. However, such variability is relatively small compared with the changes that light undergoes underwater. In shallow reef habitats, corals are frequently exposed to strong and highly fluctuating light conditions. The underwater light environment is primarily affected by: (1) temporal heterogeneity due to solar angle, (2) water surface effects, (3) depth-related spectral changes, and (4) attenuation of light intensity with depth. Among these four factors, the water surface plays the most dynamic role in shallow-water light intensity (Campbell and Aarup 1989), mostly due to wave lens effects. Our study provides the first experimental evidence of a positive effect of flicker light on coral symbiont photosynthesis.

Corals on shallow reefs are subject to highly fluctuating flicker light produced by the lens effect (Figure $1 A, B)$. Although light is the ultimate energy source of photosynthesis, exposure to excessive light intensity is a major stress factor for algal photosynthesis (Brown et al. 2000). Prolonged exposure to excessive light causes photoinhibition that may lead to irreversible photodamage, not only in corals (Jokiel 1980, Brown et al. 2000, Takahashi et al. 2004) but also in phytoplankton (Neale 1987) and seaweeds (Herbert and Waaland 1988, Huppertz et al. 1990). Photodamage in corals has been suggested as a major cause of coral bleaching in shallow reef environments (Iglesias-Prieto et al. 1992, Warner et al. 1996, Jones et al. 1998). Recent studies have suggested that photodamage of algal photosynthesis leads to dissociation of algae from the host coral, leading to coral beaching (Nakamura et al. 2005, Smith and Birkeland 2007).

Although effects of light fluctuation on photosynthesis in free-living phytoplankton have been reported, a consistent interpretation is thus far lacking. In a mixed population of phytoplankton, Fréchette and Legendre (1978) found a decrease in $\mathrm{CO}_{2}$ uptake activity under fluctuating light conditions, where- 
TABLE 3

Compound Table Showing (a) Results of Three-Way Analysis of Variance (ANOVA) of Changes in Fv/Fm in Acropora digitifera Where Supersaturating Light Regime Treatments, Temperature, and Time Are Fixed Effects and (b) Results of Tukey HSD Multiple Comparison Test on Significant Differences among the Fv/Fm of Constant and Flicker Light Treatments at Four Different Temperatures $\left(28,30,32\right.$, and $34^{\circ} \mathrm{C}$ ) Initially (I) and after $60-\mathrm{Min}$ Exposure Period (A)

\begin{tabular}{lccrc}
\hline (a) Three-way ANOVA results & df & MS & $F$ & $P$ Level \\
\hline Light treatment (L) & 1 & 0.0255 & 85.6081 & $* * *$ \\
Temperature (Temp.) & 3 & 0.0101 & 33.8311 & $* * *$ \\
Time & 1 & 1.0862 & 3648.1816 & NS \\
L $\times$ Temp. & 3 & 0.0001 & 0.2322 & $* * *$ \\
L $\times$ Time & 1 & 0.0154 & 51.7254 & NS \\
Temp. $\times$ Time & 3 & 0.0090 & 30.2672 & 1.2916 \\
L $\times$ Temp. $\times$ Time & 3 & 0.0004 & & \\
Error & 64 & 0.0003 & & \\
\hline
\end{tabular}

\begin{tabular}{|c|c|c|c|c|c|c|c|c|c|c|c|c|c|c|c|c|}
\hline \multirow{3}{*}{$\begin{array}{l}\text { (b) Post-hoc } \\
\text { results }\end{array}$} & \multicolumn{8}{|c|}{ Constant } & \multicolumn{8}{|c|}{ Flicker } \\
\hline & \multicolumn{2}{|c|}{$28^{\circ} \mathrm{C}$} & \multicolumn{2}{|c|}{$30^{\circ} \mathrm{C}$} & \multicolumn{2}{|c|}{$32^{\circ} \mathrm{C}$} & \multicolumn{2}{|c|}{$34^{\circ} \mathrm{C}$} & \multicolumn{2}{|c|}{$28^{\circ} \mathrm{C}$} & \multicolumn{2}{|c|}{$30^{\circ} \mathrm{C}$} & \multicolumn{2}{|c|}{$32^{\circ} \mathrm{C}$} & \multicolumn{2}{|c|}{$34^{\circ} \mathrm{C}$} \\
\hline & I & A & I & A & I & A & I & $\mathrm{A}$ & I & A & I & A & I & A & I & $\mathrm{A}$ \\
\hline \multicolumn{17}{|l|}{ Constant } \\
\hline $28^{\circ} \mathrm{C}$ Initial (I) & & $* * *$ & NS & $* * *$ & NS & $* * *$ & NS & $* * *$ & NS & $* * *$ & NS & $* * *$ & NS & $* * *$ & NS & $* * *$ \\
\hline $28^{\circ} \mathrm{C}$ After (A) & & & $* * *$ & NS & $* * *$ & $* *$ & $* * *$ & $* * *$ & $* * *$ & $* * *$ & $* * *$ & $* * *$ & $* * *$ & $* *$ & $* * *$ & NS \\
\hline $30^{\circ} \mathrm{C}$ Initial (I) & & & & $* * *$ & NS & $* * *$ & NS & $* * *$ & NS & $* * *$ & NS & $* * *$ & NS & $* * *$ & NS & 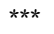 \\
\hline $30^{\circ} \mathrm{C}$ After (A) & & & & & $* * *$ & NS & $* * *$ & $* * *$ & $* * *$ & $* * *$ & $* * *$ & $* * *$ & $* * *$ & $* * *$ & $* * *$ & $\mathrm{~N}$ \\
\hline $32^{\circ} \mathrm{C}$ Initial (I) & & & & & & $* * *$ & NS & $* * *$ & NS & $* * *$ & NS & $* * *$ & NS & $* * *$ & NS & \\
\hline $32^{\circ} \mathrm{C}$ After (A) & & & & & & & $* * *$ & $* * *$ & $* * *$ & $* * *$ & $* * *$ & $* * *$ & $* * *$ & $* * *$ & $* * *$ & NS \\
\hline $34^{\circ} \mathrm{C}$ Initial (I) & & & & & & & & $* * *$ & NS & $* * *$ & NS & $* * *$ & NS & $* * *$ & NS & ** \\
\hline $34^{\circ} \mathrm{C}$ After (A) & & & & & & & & & $* * *$ & $* * *$ & $* * *$ & $* * *$ & $* * *$ & $* * *$ & $* * *$ & $* * *$ \\
\hline \multicolumn{17}{|l|}{ Flicker } \\
\hline $28^{\circ} \mathrm{C}$ Initial (I) & & & & & & & & & & $* * *$ & NS & $* * *$ & NS & $* * *$ & NS & $* * *$ \\
\hline $28^{\circ} \mathrm{C}$ After (A) & & & & & & & & & & & $* * *$ & NS & $* * *$ & $* * *$ & $* * *$ & ** \\
\hline $30^{\circ} \mathrm{C}$ Initial (I) & & & & & & & & & & & & $* * *$ & NS & $* * *$ & NS & $* * *$ \\
\hline $30^{\circ} \mathrm{C}$ After (A) & & & & & & & & & & & & & $* * *$ & * & $* * *$ & ** \\
\hline $32^{\circ} \mathrm{C}$ Initial (I) & & & & & & & & & & & & & & $* * *$ & NS & ** \\
\hline $32^{\circ} \mathrm{C}$ After (A) & & & & & & & & & & & & & & & $* * *$ & $* * *$ \\
\hline $34^{\circ} \mathrm{C}$ Initial (I) & & & & & & & & & & & & & & & & $* * *$ \\
\hline $34^{\circ} \mathrm{C}$ After (A) & & & & & & & & & & & & & & & & \\
\hline
\end{tabular}

Note: Asterisks indicate significant difference: ${ }^{*}, P<.05 ;{ }^{* *}, P<.01$; ${ }^{* *}, P<.001$; NS, no significant difference.

as Walsh and Legendre (1983) showed a higher $\mathrm{CO}_{2}$ uptake activity under fluctuating light conditions. Using a monoculture of $\mathrm{Du}$ naliella tertiolecta (Chrolophyta) grown under fluctuating light conditions, Queguiner and Legendre (1986) reported a decrease in photosynthetic efficiency. We consider it plausible that this discrepancy in results can be ascribed to the difference in the light intensity applied (Stramski et al. 1993). In Figure 2 , we have drawn a light response curve of the symbiotic algae to determine the optimal light intensity. An optimal light intensity for photosynthesis varies among species, and it can be influenced by physical parameters such as temperature, $\mathrm{CO}_{2}$ availability, and nutrients. Thus, it is important to know an optimal light intensity for each condition to assess flicker light effects. In this context, we suggest that flicker light effects vary among light intensities and species (Figures 4 and 5).

This study demonstrates that flicker light at a supersaturating light intensity reduces photoinhibition of coral photosynthesis 


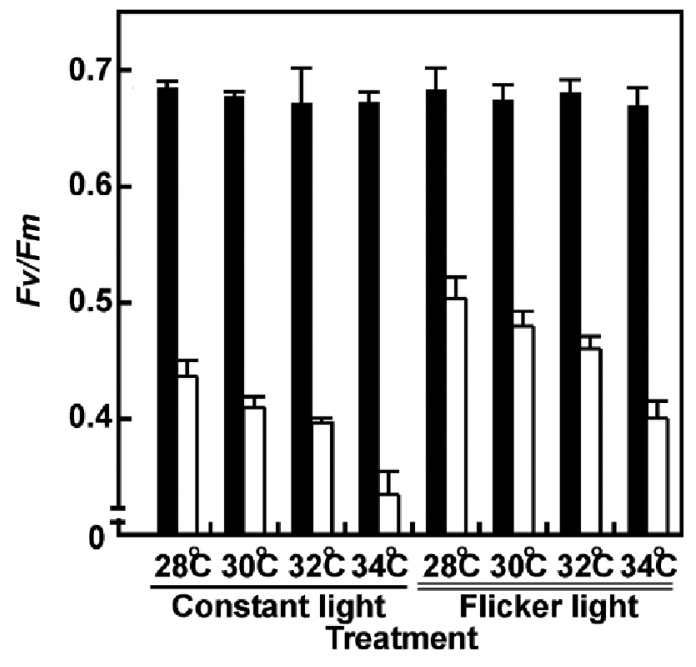

Figure 5. Fv/Fm (mean $\pm \mathrm{SD}, n=5$ ) for $A$. digitifera before (black bars) and after $60 \mathrm{~min}$ (white bars) of exposure to either constant light $(500 \mu \mathrm{mol}$ photons $\mathrm{m}^{-2} \cdot \mathrm{sec}^{-1}$ ) or Flicker treatment $\mathrm{C}$ (integral light intensity: $502 \mu \mathrm{mol}$ photons $\cdot \mathrm{m}^{-2} \cdot \mathrm{sec}^{-1}$ ) at four temperatures $\left(28,30,32\right.$, and $\left.34^{\circ} \mathrm{C}\right)$.

(Figure 4). It should be noted that the effect is pronounced at elevated seawater temperatures (Figure 5), a condition where photodamage in corals is amplified (Jones and Hoegh-Guldberg 2001, Lesser and Farrell 2004, Takahashi et al. 2004, Smith and Birkeland 2007). That is, elevated seawater temperatures exacerbate the effects of photoinhibition, but flicker light reduces photoinhibition. We may speculate on a potential hypothesis to explain how flicker light condition reduced photoinhibition in A. digitifera: The degree of photoinhibition would be suppressed because of the shorter duration of the integrated period of supersaturating light under flicker light conditions, compared with the continuous supersaturating light regime. Therefore, during calm water conditions, corals would suffer a greater degree of photoinhibition due to the exposure to continuous supersaturating light. At the same time, corals would not experience periods of subsaturating light exposure, which is essential for the repair process of a damaged photosynthetic apparatus.

Calm conditions are often related to an el- evation of water temperature and a reduction of water circulation in shallow reef environments, and these factors in combination can greatly increase risk of coral bleaching. The hypothesis that less water circulation increases the tendency for bleaching (Nakamura and van Woesik 2001) is supported by a field observation (Loya et al. 2001) and experiments (Nakamura et al. 2005, Nakamura and Yamasaki 2005, Ulstrup et al. 2005, Finelli et al. 2006, Smith and Birkeland 2007). In the worst-case scenario, calm conditions accompanied by flattened water surface may facilitate severe bleaching in shallowinhabiting corals because the smooth water surface minimizes flicker light.

\section{ACKNOWLEDGMENTS}

We thank Y. Nakano, S. Nakamura, and the faculty of Sesoko Tropical Biosphere Research Station, University of the Ryukyus, Japan, for technical support and advice. We extend our gratitude to an anonymous reviewer for constructive and thoughtful suggestions on the manuscript.

\section{Literature Cited}

Aro, E. M., I. Virgin, and B. Andersson. 1993. Photoinhibition of Photosystem II: Inactivation, protein damage and turnover. Biochem. Biophys. Acta 1143:113-134.

Barber, J., and B. Andersson. 1992. Too much of a good thing: Light can be bad for photosynthesis. Trends Biochem. Sci. 17:61-66.

Brown, B. E., R. P. Dunne, T. P. Scoffin, and M. D. A. LeTissier. 1994. Solar damage in intertidal corals. Coral Reefs 105:219-230.

Brown, B. E., R. P. Duune, M. E. Warner, I. Ambarsari, W. K. Fitt, W. W. Gibb, and D. G. Cummings. 2000. Damage and recovery of Photosystem II during a manipulative field experiment on solar bleaching in the coral Goniastrea aspera. Mar. Ecol. Prog. Ser. 195:117-124.

Campbell, J. W., and T. Aarup. 1989. Photosynthetically available radiation at high latitudes. Limnol. Oceanogr. 34:1490-1499.

Demmig, B., and O. Bjorkman. 1987. Com- 
parison of the effect of excessive light on chlorophyll fluorescence $(77 \mathrm{~K})$ and photon yield of $\mathrm{O}_{2}$ evolution in leaves of higher plants. Planta (Berl.) 171:171-184.

Drew, E. A. 1983. Light. The ecology of the shallow sublittoral benthos. Pages 10-57 in R. Earll and D. G. Erwin, eds. Sublittoral ecology. Clarendon Press, Oxford, United Kingdom.

Falkowski, P. G., P. L. Jokiel, and R. A. Kinzie III. 1990. Irradiance and corals. Pages 89-107 in Z. Dubinsky, ed. Ecosystems of the world: 25-Coral reefs. Elsevier, Amsterdam.

Finelli, C. M., B. S. T. Helmuth, N. D. Pentcheff, and D. S. Wethey. 2006. Water flow influences oxygen transport and photosynthetic efficiency in corals. Coral Reefs 25:47-57.

Franklin, L. A., G. Levavasseur, C. B. Osmond, W. J. Henley, and J. Ramus. 1992. Two components of onset and recovery during photoinhibition of Ulva rotundata. Planta (Berl.) 186:399-408.

Fréchette, M., and L. Legendre. 1978. Photosynthèse phytoplanctonique: Réponse à un stimulus simple, imitant les variations rapides de la lumière engendrées par les vagues. J. Exp. Mar. Biol. Ecol. 32:15-25.

Herbert, S. K., and J. R. Waaland. 1988. Photoinhibition of photosynthesis in a sun and a shade species of the red algal genus Porphyra. Mar. Biol. (Berl.) 97:1-7.

Huppertz, K. D., D. Hanelt, and W. Nultsch. 1990. Photoinhibition of photosynthesis in the marine brown alga Fucus serratus as studied in field experiments. Mar. Ecol. Prog. Ser. 66:175-182.

Iglesias-Prieto, R., J. L. Matta, W. A. Robins, and R. K. Trench. 1992. Photosynthetic response to elevated temperature in the symbiotic dinoflagellate Symbiodinium microadriaticum in culture. Proc. Natl. Acad. Sci. U.S.A. 89:10302-10305.

Jokiel, P. L. 1980. Solar ultraviolet radiation and coral reef epifauna. Science (Washington, D.C.) 207:1069-1071.

Jones, R. J., and O. Hoegh-Guldberg. 2001. Diurnal changes in the photochemical efficiency of the symbiotic dinoflagellates (Dinophyceae) of corals: Photoprotection, photoinactivation and the relationship to coral bleaching. Plant Cell Environ. 24:88-99.

Jones, R., O. Hoegh-Guldberg, A. W. L. Larkum, and U. Schreiber. 1998. Temperature induced bleaching of corals begins with impairment of dark metabolism in zooxanthellae. Plant Cell Environ. 21:1219-1230.

Kirk, J. T. O. 1994. Light and photosynthesis in aquatic ecosystems. Cambridge University Press, Cambridge, United Kingdom.

Larkum, A. W. D., and J. Barrett. 1983. Light-harvesting processes in algae. Adv. Bot. Res. 10:1-219.

Lesser, M. P., and J. M. Farrell. 2004. Exposure to solar radiation increases damage to both host tissues and algal symbionts of corals during thermal stress. Coral Reefs 23:367-377.

Loya, Y., K. Sakai, K. Yamazato, Y. Nakano, H. Sambali, and R. van Woesik. 2001. Coral bleaching: The winners and the losers. Ecol. Lett. 4:122-131.

Muscatine, L. 1967. Glycerol excretion by symbiotic algae from corals and Tridacna and its control by the host. Science (Washington, D.C.) 156:516-519.

Nakamura, T., and R. van Woesik. 2001. Water-flow rates and passive diffusion partially explain differential survival of corals during 1998 bleaching event. Mar. Ecol. Prog. Ser. 212:301-304.

Nakamura, T., R. van Woesik, and H. Yamasaki. 2005. Photoinhibition of photosynthesis is reduced by water flow in the reef-building coral Acropora digitifera. Mar. Ecol. Prog. Ser. 301:109-118.

Nakamura, T., and H. Yamasaki. 2005. Requirement of water flow for sustainable growth of pocilloporid corals during high temperature periods. Mar. Pollut. Bull. 50:1115-1120.

Neale, P. J. 1987. Algal photoinhibition and photosynthesis in the aquatic environment. Pages 39-65 in D. J. Kyle, C. B. Osmond, and C. J. Arntzen, eds. Topics in photosynthesis. Vol. 9. Photoinhibition. Elsevier, Amsterdam.

Osmond, C. B. 1994. What is photoinhibition? Some insight from comparisons of 
shade and sun plants. Pages 1-24 in N. R. Baker and J. R. Bowyer, eds. Photoinhibition of photosynthesis from molecular mechanisms to the field. Bios Scientific Publishers, Oxford, United Kingdom.

Queguiner, B., and L. Legendre. 1986. Phytoplankton photosynthetic adaptation to high frequency light fluctuations simulating those induced by sea surface waves. Mar. Biol. (Berl.) 90:483-491.

Schreiber, U., T. Endo, H. L. Mi, and K. Asada. 1995. Quenching analysis of chlorophyll fluorescence by the saturation pulse method: Particular aspects relating to the study of eukaryotic algae and cyanobacteria. Plant Cell Physiol. 36:873-882.

Schreiber, U., U. Schliwa, and W. Bilger. 1986. Continuous recording of photochemical and non-photochemical chlorophyll fluorescence quenching with a new type of modulation fluorometer. Photosynth. Res. 10:51-62.

Schubert, H., S. Sagert, and M. R. Foster. 2001. Evaluation of the different levels of variability in the underwater light field of a shallow estuary. Helgol. Mar. Res. $55: 12-22$.

Smith, L. W., and C. Birkeland. 2007. Effects of intermittent flow and irradiance level on back reef Porites corals at elevated seawater temperatures. J. Exp. Mar. Biol. Ecol. 341:282-294.

Stramski, D., G. Rosenberg, and L. Legen- dre. 1993. Photosynthetic and optical properties of the marine chlorophyte $D u$ naliella tertiolecta grown under fluctuating light caused by surface-wave focusing. Mar. Biol. (Berl.) 115:363-372.

Takahashi, S., T. Nakamura, M. Sakamizu, R. van Woesik, and H. Yamasaki. 2004. Repair machinery of symbiotic photosynthesis as the primary target of heat stress for reef-building corals. Plant Cell Physiol. 45:251-255.

Ulstrup, K. E., R. Hill, and P. J. Ralph. 2005. Photosynthetic impact of hypoxia on in hospite zooxanthellae in the scleractinian coral Pocillopora damicornis. Mar. Ecol. Prog. Ser. 286:125-132.

Walsh, P., and L. Legendre. 1983. Photosynthesis of natural phytoplankton under high frequency light fluctuations simulating those produced by sea surface waves. Limnol. Oceanogr. 28:688-697.

Warner, M. E., G. C. Chilcoat, F. K. McFarland, and W. K. Fitt. 2002. Seasonal fluctuations in the photosynthetic capacity of Photosystem II in symbiotic dinoflagellates in the Caribbean reef-building coral Montastrea. Mar. Biol. (Berl.) 141:31-38.

Warner, M. E., W. K. Fitt, and G. W. Schmidt. 1996. The effects of elevated temperature on the photosynthetic efficiency of zooxanthellae in hospite from four different species of reef coral: A novel approach. Plant Cell Environ. 19:291-299. 